\title{
Microcystin Biodegradation Study Using a Lagoa Dos Patos Estuary Sediment in Southern of Brasil and a Comparative Analysis of Biodegradation with Isolated Bacteria
}

\author{
Gilmar A. F. Lemes, ${ }^{1, *}$, João S. Yunes ${ }^{2}$ \\ ${ }^{1}$ Laboratório de Cianobactérias e Ficotoxinas, Av. Itália Km 08, 96201-900, Rio Grande-RS, Brasil \\ ${ }^{2}$ Universidade Federal do Rio Grande, FURG, Brazil \\ *Corresponding author: antoniofarias135@gmail.com
}

\begin{abstract}
In the Lagoa dos Patos Estuary, southern Brazil, toxic blooms of cyanobacteria have been recorded for many years. Among the species of cyanobacteria that occur in the estuary Microcystis aeruginosa produces the toxin [D-Leu $\left.{ }^{1}\right]$ microcystin-LR, one of the most toxic known variants. The strain Microcystis aeruginosa RST9501 was cultivated in Cyanobacteria and Phycotoxins Lab of the Oceanography Institute of the Federal University of Rio Grande - FURG and it was used for toxin extraction and purification. Sediment samples were collected from the estuary and used in the toxin degradation experiments. The decrease of toxin concentration was checked by HPLC and the results were compared with other available data. This study revealed the decreased of toxin [D-Leu $\left.{ }^{1}\right]$ microcystin-LR concentration of $5 \mu \mathrm{g} \cdot \mathrm{mL}^{-1}$ after six days, and also describes a comparative analysis of the biodegradation by the sediment and with a bacterium isolated from the collected sediment samples. It was suggested that the reduction in toxin concentration is mainly due the biodegradation by the bacterial community of Lagoa dos Patos Estuary present in the sediment. This confirms the potential of this technique as a complementary tool for biotechnological processes to remove toxins in water. It was also carried out a comparative analysis of the biodegradation of the toxin with sediment and biodegradation with an isolated bacteria from this sediment.
\end{abstract}

Keywords: bacteria, biodegradation, cyanobacteria, sediment, microcystin, comparative analysis

Cite This Article: Gilmar A. F. Lemes, and João S. Yunes, "Microcystin Biodegradation Study Using a Lagoa Dos Patos Estuary Sediment in Southern of Brasil and a Comparative Analysis of Biodegradation with Isolated Bacteria." International Journal of Environmental Bioremediation \& Biodegradation, vol. 5, no. 2 (2017): 41-48. doi: 10.12691/ijebb-5-2-2.

\section{Introduction}

The occurrence of toxic cyanobacterial blooms has been reported for more than 20 years in the Lagoa dos Patos Estuary [21,36,38]. The predominant species of cyanobacteria in the estuary, Microcystis aeruginosa, is known for producing hepatotoxin [D-Leu $\left.{ }^{1}\right]$ microcystinLR ([D-Leu $\left.{ }^{1}\right]$ MC-LR) $[22,23]$, which represents $90 \%$ of all toxins produced intracellularly. The hepatotoxicity of this variant has already been reported through animals and enzymatic bioassays data. It was found to be one of the most toxic hepatotoxins [22] and it has been classified by the IARC (International Agency for Research on Cancer) as a possible carcinogen in humans [6].

Microcystins (MCs) are cyclic heptapeptides that contain a characteristic section called $\beta$-amino,3-amino-9methoxy-2-6,8-trimethyl-10-phenyl-deca-4,6-dienoic acid (ADDA) [13], which is responsible for the toxicity of the compound. More than 70 structural variants have been described in the literature. These toxins promote tumors and are involved in acute and chronic health problems in humans and animals.

Toxins from cyanobacteria represent risks for the human population by the exposure through drinking water or when swimming or fishing in contaminated water. The presence of cyanobacteria and their toxins represents a series of changes that cause damage to the environment and they can affect all levels of the trophic chain [35].

The Lagoa dos Patos is the most important watershed of Southern Brazil. This region has an area of about $10,227 \mathrm{~km}^{2}$ which is used as a place for food, shelter and breeding of a large number of species of fish and shellfish. Lagoa dos Patos and its estuary represent the second largest volume of natural inland waters of the country. Its waters cross the most industrialized areas of the state of Rio Grande do Sul. On its shores live more than 3 million inhabitants in several cities and villages using its waters for leisure, public supply, industries, commercial and subsistence fishing, agriculture and navigation [40].

Lagoa dos Patos Estuary receive a high nutrient load, probably because of the contamination by domestic sewage and of the discharge of industrial waste coming 
from cities located on its margins, especially from the city of Rio Grande [36,39]. Because of this contamination, the sediment of the estuary is rich in organic compounds that nourishes a wide variety of bacterial genera.

Considering the importance of this environment, the occurrence of cyanobacterial blooms and the consequent liberation of toxins means an environmental problem affecting the ecosystem and the bordering estuary communities.

Although studies have been carried out using lake sediments for the degradation of a variety of toxic compounds such as microcystins and Polycyclic Aromatic Hydrocarbons (PAHs) [2,7,11,27,28], the dynamic of the elimination of toxic compounds in sediment and which involved organisms are not precisely known yet.

This study aims to identify the use of sediment from the Lagoa dos Patos Estuary as a substrate with potential for the biodegradation of toxin [D-Leu ${ }^{1}$ microcystin-LR and as a source of bacteria carrying enzymes capable of biodegrading this compound, as well as to compare the process of biodegradation with the sediment and from a bacterial strain isolated from this sediment.

\section{Materials and Methods}

\subsection{Culturing the Cyanobacteria Strain}

A Microcystis strain cataloged as Microcystis aeruginosa - RST9501 was cultured at the culture collection of the Cyanobacteria and Phycotoxins Laboratory of the Institute of Oceanography from the Federal University of Rio Grande - FURG. The strain was cultured in a $1 \mathrm{~L}$ Erlenmeyer flask using the liquid BG-11 medium [29] in a temperature-controlled room $\left(20^{\circ} \mathrm{C} \pm\right.$ ). The room was lit by two fluorescent lamps to provide a radiation equivalent to $125 \mu \mathrm{E} \cdot \mathrm{m}^{-2} \cdot \mathrm{s}^{-1}$. The Microcystis RST9501 strain is a producer of the toxin [D-Leu ${ }^{1}$ ] microcystin-LR and following the culture, toxin material was obtained for its extraction, which is detailed below.

\subsection{Toxin Extraction Process}

Extraction and semi-purification processes of the toxin began with samples of the RST9501 following the method described by Lawton et al. [15]. The culture samples were collected and centrifuged in a HERMLE Labnet Z323, centrifuge at $8,000 \mathrm{~g}$ for 20 minutes. Next the centrifuged material was frozen and lyophilized (EDWARDS MicroModulyo). Then, it was added $250 \mathrm{ml}$ of acetic acid $(5 \% \mathrm{v} / \mathrm{v})$ for each gram of lyophilized material, and the mixture was shaken and centrifuged once more at $8,000 \mathrm{~g}$ for 10 minutes. The resulting supernatant $\left(\mathrm{S}_{1}\right)$ was stored. The pellet from this first round of centrifugation went through a second round of the same process described above. After centrifugation of the mixture at $8,000 \mathrm{~g}$ for 10 minutes, the pellet was discarded, and the supernatant $\left(\mathrm{S}_{2}\right)$ was added to the previous supernatant $\left(\mathrm{S}_{1}\right)$. The resulting $500 \mathrm{ml}$ from the supernatants $\left(S_{1}+S_{2}\right)$ was kept in a freezer for 24 hours. After thawing, the extract was centrifuged once more at $8,000 \mathrm{~g}$ for 10 minutes, and the resulting pellet was discarted.

For the second stage, the extract was passed through 3 $\mathrm{ml} / \mathrm{g} \mathrm{C}_{18}$ cartridges (Sep-Pak cartridges) on a peristaltic pump (Millipore Corporation, USA). The $\mathrm{C}_{18}$ cartridges was previously activated with the passage of $10 \mathrm{ml}$ of methanol, followed by $10 \mathrm{ml}$ of distilled water. After, the extracts were passed through these cartridges, they were frozen in the cartridges for 24 hours. After thawing, the cartridges were eluted with $20 \mathrm{~mL}$ of $(100 \%)$ methanol, and the extracts obtained from the cartridges were dried in a rotary evaporator at $40^{\circ} \mathrm{C}$ under vacuum. After evaporation, the residues were resuspended with two volumes of $500 \mu \mathrm{L}$ of $(100 \%)$ methanol; Then, they were analyzed by high performance liquid chromatography (HPLC - Shimadzu SCL-10A $\mathrm{vp}_{\mathrm{vp}}$ - Japan) to determine the concentration of microcystins. This semi-purified toxin (Figure 1) was used for the sediment experiment.

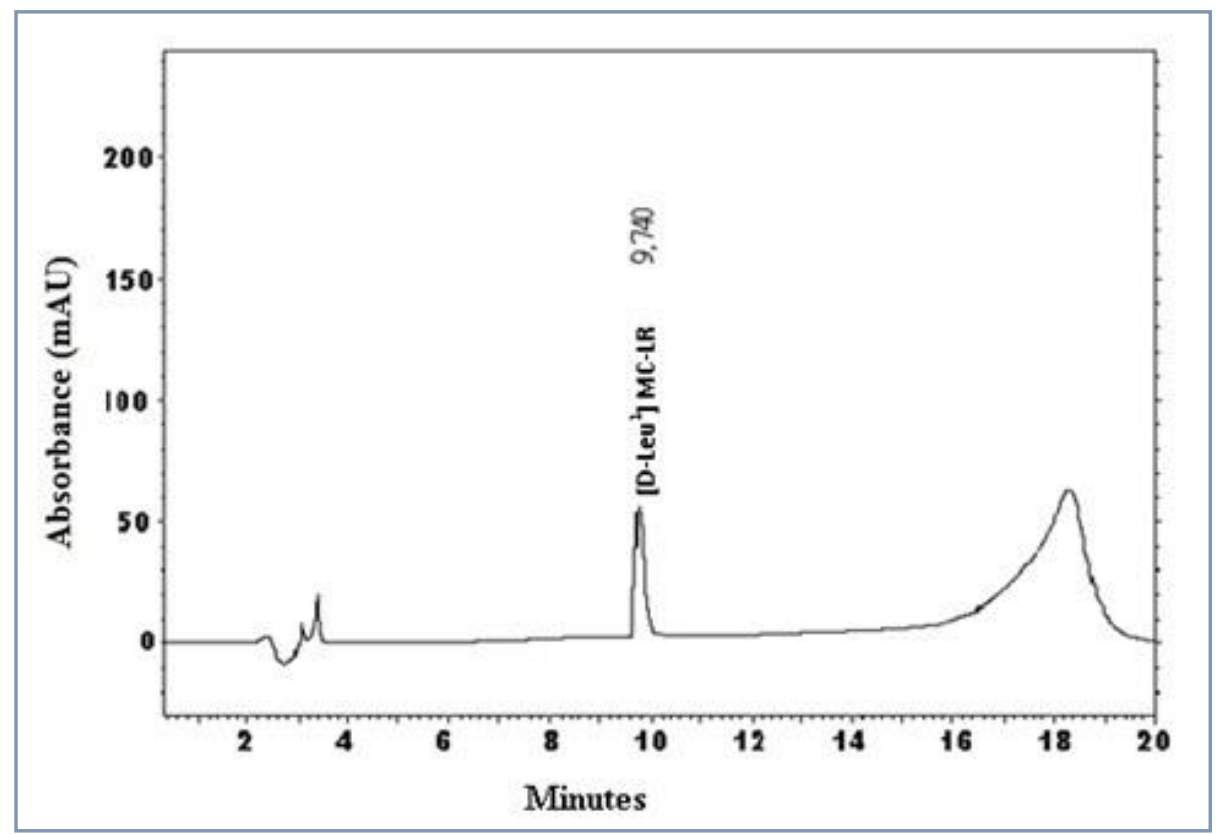

Figure 1. Chromatogram of the toxin [D-Leu $\left.{ }^{1}\right]$ MC-LR obtained during the extraction process with the Microcystis aeruginosa strain RST9501. Fraction with a purity greater than 95\%. (AU) Absorbance Unit 


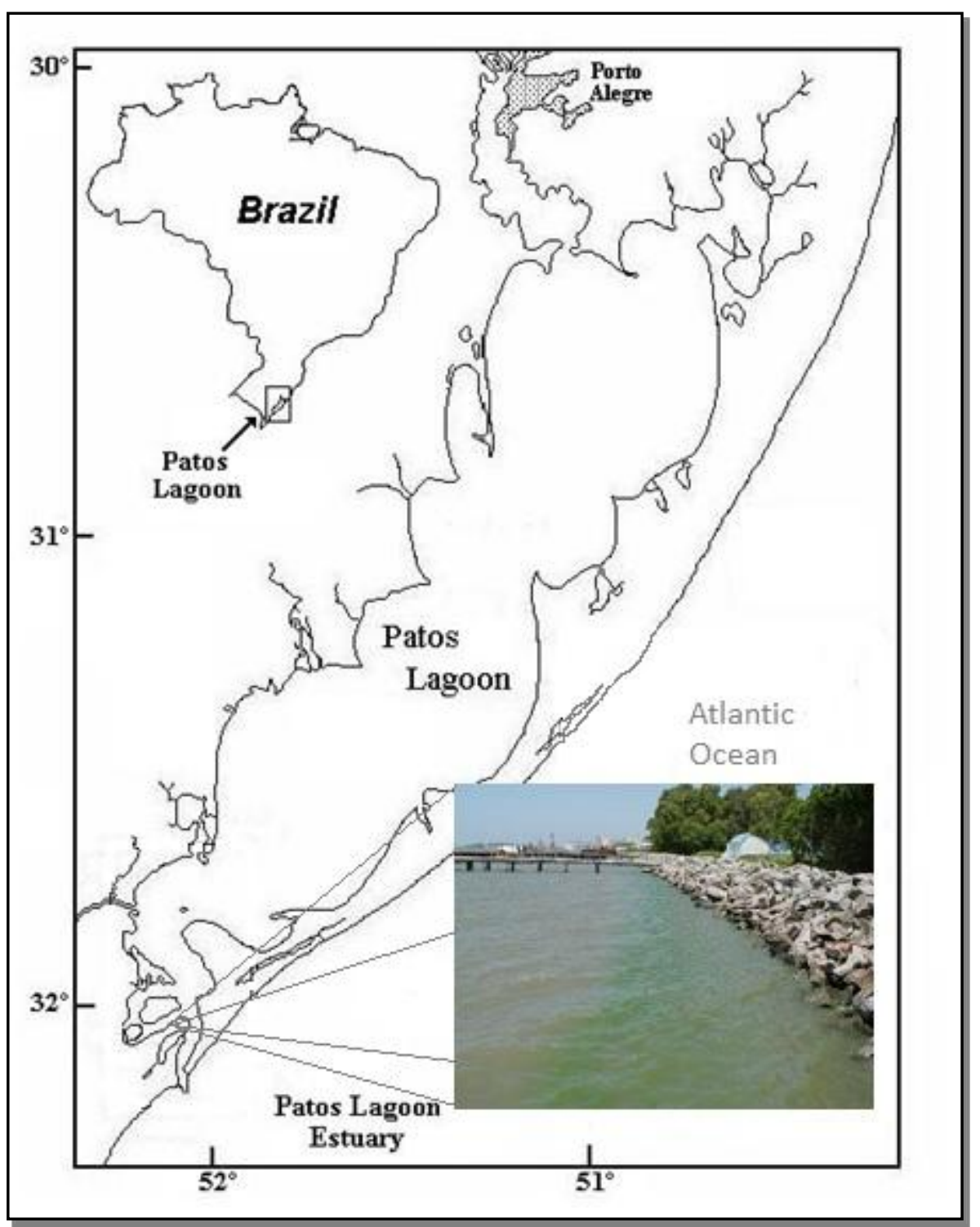

Figure 2. Location for the sediment collection of and water. The site was located next to the Oceanographic Museum of the University of Rio Grande FURG, in the Lagoa dos Patos Estuary - RS, (state of Rio Grande do Sul, southern Brazil)

\subsection{Collection of Water Samples and Sediment of Lagoa Dos Patos Estuary}

Lagoa dos Patos surface is about $10,227 \mathrm{Km}^{2}$ and the estuary in the southerneast part covers $900 \mathrm{Km}^{2}$; the average depth varies from a few centimeters to approximately 5 meters and it can be classified as a shallow lake (Figure 2). Samples of sediment were collected from the estuarine region (near the Oceanographic Museum of Federal University of Rio Grande - FURG) to serve as material for the toxin degradation tests. The estuary point next to the Oceanographic Museum was chosen because of the cyanobacterial blooms have historically occurred there [39].

Samples of sediment were collected with a PVC sampler. After the samples were placed in a plastic bucket and later stored in sterile plastic $500 \mathrm{ml}$ flasks. The water temperature (thermometer - INCOTERM) and the salinity (salinometer - QUIMIS) were measured at the location. The $\mathrm{pH}$ was measured at the laboratory $(\mathrm{pH}$ meter, model Marte - DIGIMED). Samples of sediment around 500g were taken to the laboratory where they were stored at \pm $4^{\circ} \mathrm{C}$ until the experiment.

\subsection{Concentration of the Toxin [D-Leu ${ }^{1}$ ] Microcystin-LR by Hplc}

The analysis to determine toxin concentration were also carried out through a Shimadzu SCL-10Avp chromatograph, which was equipped with a UV-SPD 10Avp detector, a quaternary $\mathrm{LC}-10 \mathrm{AD}_{\mathrm{vp}}$ pump and a CTO-10As $\mathrm{Ap}_{\mathrm{vp}}$ column oven and controlled by CLASS-VP 6.21 SP5 software. For this analysis a $\mathrm{C}_{18}$ column was used. The maximum peak of absorption for microcystin was $238 \mathrm{~nm}$, so the wavelength for reading was adjusted to this value. The samples for the experiment were centrifuged in Eppendorf tubes for 20 minutes, and then, $200 \mu \mathrm{L}$ of each sample was injected into the HPLC Shimadzu SCL-10Avp and tracked for a running time of about 10 minutes. Reduction of the toxin concentration was indicated by lower peaks on the [D-Leu ${ }^{1}$ ] microcystin-LR toxin chromatograms, as shown in Figure 3. 


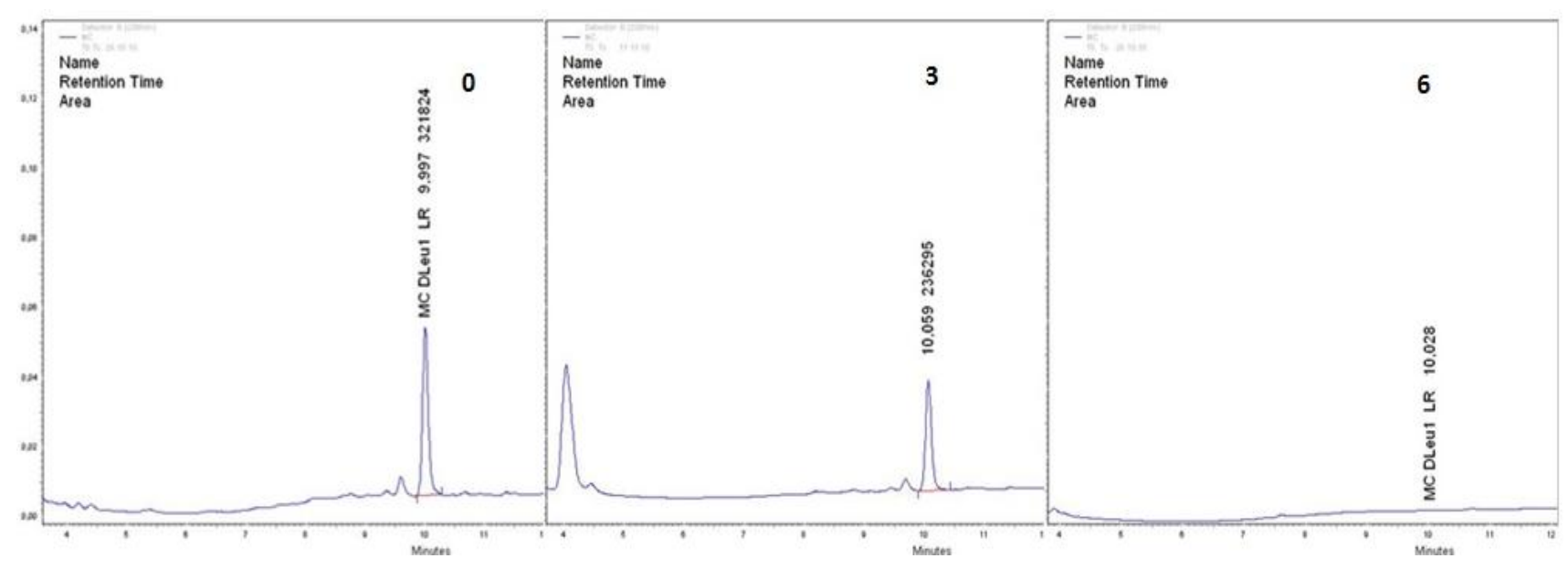

Figure 3. Chromatograms showing the chromatographic peaks for the toxin [D-Leu $\left.{ }^{-1}\right]$ microcystin-LR using estuarine sediment. Panel 0 (beginning), Panel 3 (three days later) and Panel 6 (six days later) represent the decreases in toxin as analyzed by HPLC. Numbers above each chromatogram peak show the toxin retention time in minutes and area of the toxin peak

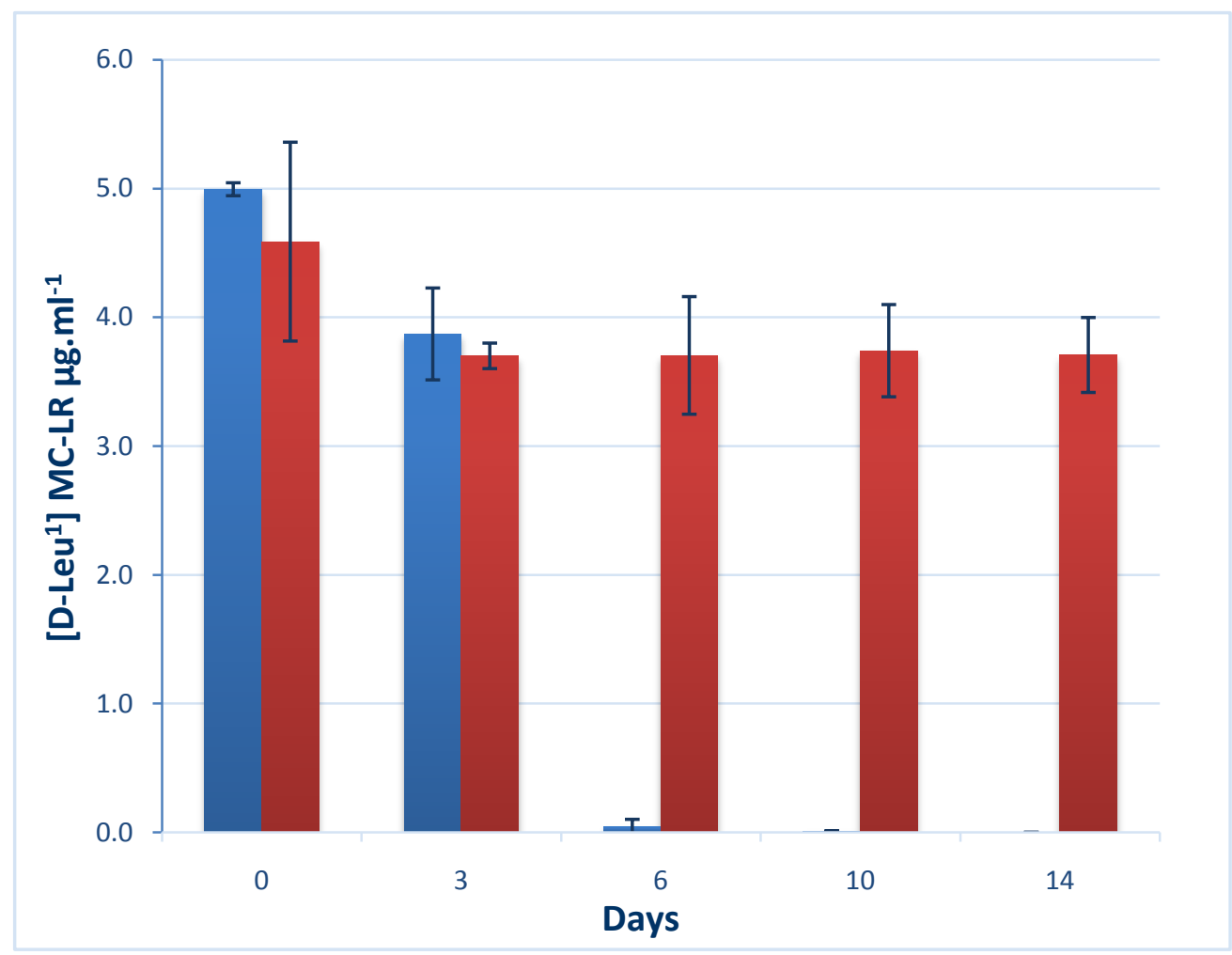

Figure 4. Degradation of the $\left[\mathrm{D}-\mathrm{Leu}^{-1}\right]$ microcystin-LR toxin using estuarine sediment from Lagoa dos Patos - RS.

Treatment,

Control

\section{5. [D-Leu $\left.{ }^{1}\right]$ Microcystin-LR Biodegradation Experiment with Sediment from the Estuary}

Biodegradation of $\left[\mathrm{D}-\mathrm{Leu}^{1}\right]$ microcystin-LR was performed with the samples of collected sediment containing $29 \mathrm{ml}$ of minimal salt medium (MSM, [25]). They were placed in six amber-colored flasks, three flasks for treatments and three for controls. To each flask $1 \mathrm{~g}$ of sediment was added in order to obtain a volume of approximately $30 \mathrm{ml}$. Next, it was added $21 \mu \mathrm{L}$ of the toxin

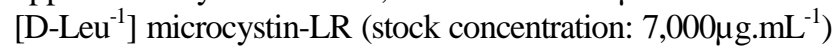
to each flask in order to obtain an average concentration of $5 \mu \mathrm{g} \cdot \mathrm{ml}^{-1}$. The samples of sediment that served as controls were all autoclaved at $120 \mathrm{Kgf} / \mathrm{cm}^{2}$ for 30 minutes. All experimental and control flasks were then placed in a
CERTOMAT® BS-1 incubator-shaker (Germany) at a temperature of $27^{\circ} \mathrm{C}$ (Figure 4).

Every three days, samples for the experiment were collected while under a microbiological hood using a Bunsen burner. The average time from the collection of experimental samples to analysis was three days, and the total time for sampling was 30 days. Samples from the experiment were placed in labeled Eppendorf tubes and stored in a freezer $\left(-20^{\circ} \mathrm{C}\right)$ for later analysis by HPLC.

\subsection{Isolation of Bacterial Strains}

Samples of collected sediment, were inoculated in Petri dishes containing $15 \mathrm{~g} . \mathrm{L}^{-1}$ of agar in MSM with $8 \mathrm{~g} . \mathrm{L}^{-1}$ of anhydrous glucose. The dishes inoculated with sediment samples were placed in the CERTOMAT® BS-1 
incubator-shaker (Germany) at a temperature of $27^{\circ} \mathrm{C}$. From these samples, seven bacterial strains were isolated and showed different color characteristics and colonies shape.

\subsection{Comparative Analysis of [D-Leu ${ }^{1}$ ] MC-LR Biodegradation with the Use of the Lagoa Dos Patos Estuary Sediment and with a Bacterial Strain Isolated from This Sediment}

From the sediment collected samples of the Lagoa dos Patos estuary, biodegradation experiments were carried out and some strains were isolated from this sediment (Table 1). One of this isolated bacteria was applied to confirm the potential degradation of the strain. The selected bacterium was DMXS [19]. In the experiment carried out, an approximate concentration of $1 \mu \mathrm{g} . \mathrm{L}^{-1}$ of [D-Leu ${ }^{1}$ ] MC-LR was used and the experiment was extended for 24 days.

During the experiment, it was possible to evaluate the decrease in toxin concentration while an increase in bacterial density occurred. In this experiment, the decrease in toxin concentration was also evaluated by HPLC and the identification of the bacterium was carried out by molecular biology analyzes through genetic sequencing and the results were published.

The use of this research data [19] with obtained data with biodegradation of the [D-Leu $\left.{ }^{1}\right]$ MC-LR with sediment utilization made possible a comparative analysis of the sediment use efficiency and the capacity of the bacterium selected in decreasing or eliminating the concentration of toxin present in the water (Figure 5).

\section{Results}

Sediment samples from Lagoa dos Patos Estuary were collected and their potential to induce the reduction of the concentration of [D-Leu $\left.{ }^{1}\right]$ microcystin-LR toxin was evaluated. From the sediment samples, seven strains of bacteria were successfully isolated (See Table 1).

Indication of the removal of the $\left[\mathrm{D}-\mathrm{Leu}^{-1}\right]$ microcystinLR toxin during the experiment was also obtained by the reduction of the chromatographic peak. The peak was observed precisely ten minutes into the chromatographic run, with an absorption spectrum of $238 \mathrm{~nm}$ for microcystin. The Figure 3 Displays three chromatograms from the treatment at three different times, showing the disappearance of the microcystin peaks over the course of the experiment.

The initial concentration of toxin was approximately $5 \mu \mathrm{g} \cdot \mathrm{mL}^{-1}$. The entire concentration of [D-Leu ${ }^{1}$ ] microcystin-LR toxin was eliminated after 6 days, and concentration values of zero were maintained until the end of the experiment. The control samples remained largely stable: there was a decrease of $22 \%$ through the third day, and after this the concentration stabilized until the end of the experiment (Figure 4).

The constant for exponential decay was calculated with the program Excel 2003 (Microsoft, Windows XP), and the half-life was calculated based on the equation supplied with the program.

The comparative analysis between the experiment with the sediment and the experiment with the isolated bacteria allowed the generation of the Figure 5, which allows a view of the toxin removal efficiency in parallel in two studies. Sediment removal is quicker to reach $100 \%$ of the toxin added.

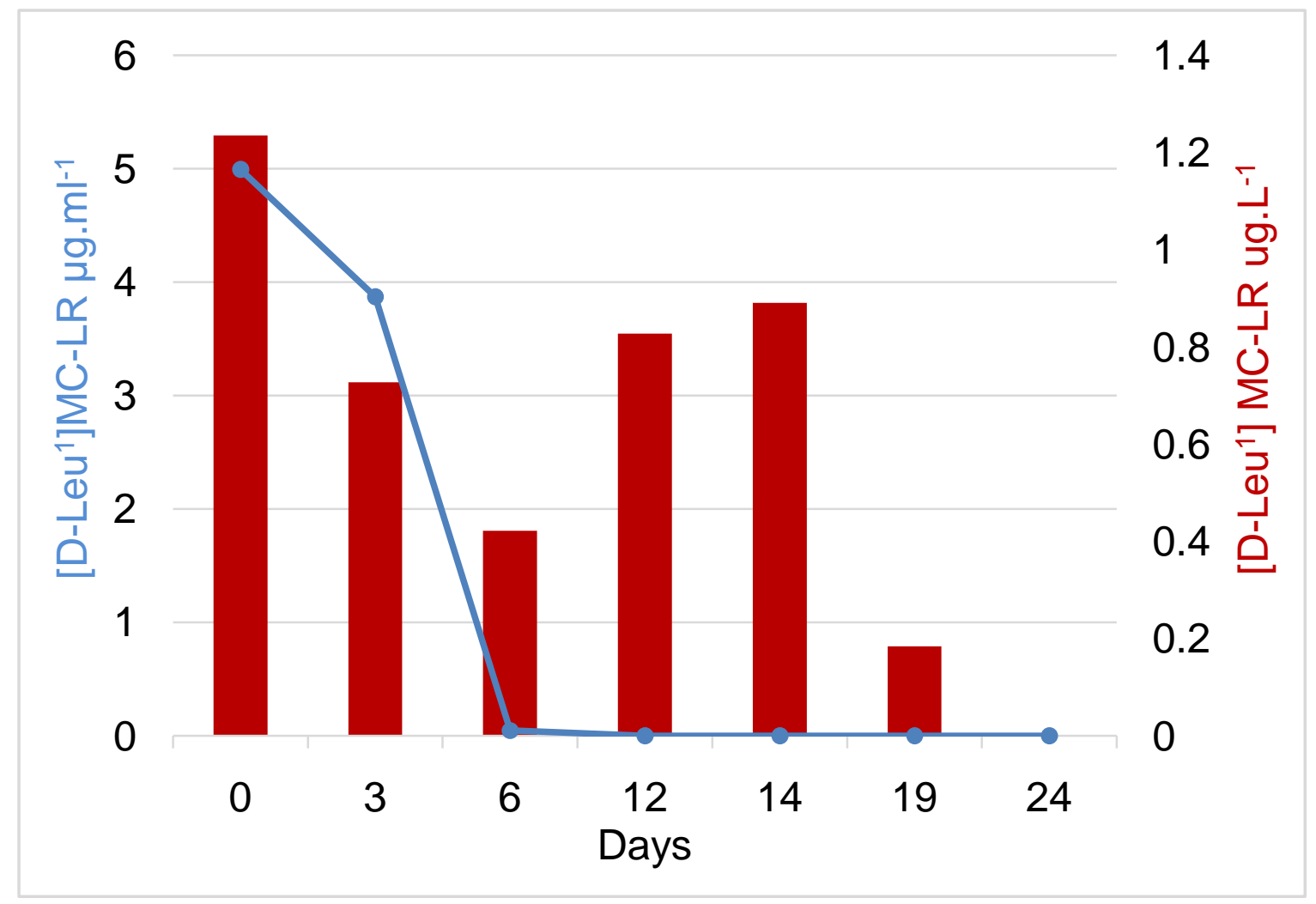

Figure 5. Comparative analysis between the efficiency of sediment use (O) and the isolated bacteria for the biodegradation of cyanotoxin [D-Leu ${ }^{-1}$ ] microcystin-LR( $\mathbf{a})$ 
Table 1. Bacteria isolated from water and sediment samples collected in Lagoa dos Patos Estuary (near the Oceanographic Museum) (Rio Grande do Sul, State, Brazil)

\begin{tabular}{lcc}
\hline Bacterial & Color colony & Source \\
\hline BM12 & Yellow & Water \\
EE1 & White & Water \\
LPML & Orange & Water \\
NOT13 & Yellow & Water \\
CEV & Red & Water \\
FB0607 & Red & Water \\
DMXS & Light brown & Sadiment \\
\hline
\end{tabular}

\section{Discussion}

Experiments using sediments from lakes, rivers and estuaries to assess biodegradation of microcystins have been performed in various countries, including Finland [27], China [2,3] and Germany [7]. The analyses of factors that affect biodegradation, such as temperature, oxygen content and quantity of nutrients, have been verified in experiments with oxic and anoxic conditions $[3,11]$.

Bacteria act by modifying environmental physicochemical conditions. Thus, it is thought that bacteria in sediment plays an important role in the decomposition of organic matter and in geochemical cycles. These microorganisms are adapted to efficiently exploit different sources of energy [26] and the sediment has a fundamental role as sources of bacteria for the water column.

The sediment sampling of Lagoa dos Patos estuary site has environmental characteristics typical of an estuary with predominantly sandy sediments and a slightly alkaline $\mathrm{pH}$ that is normal for environments with marine influences. This type of sediment presents a variable redox potential, because it acts as oxidants. In the Lagoa dos Patos sediment, high concentrations of phosphorus [31] and metal contamination have been identified, probably because of the dynamic estuary subjected to strong anthropic influences. Considering all these characteristics, the high dynamic of the place is subjected to wave action and the entrance nutrients. This implies that this area should contain large concentration of bacteria. In this study, however, we cultured samples of the sediment and it was obtained seven strains of bacteria using MSM with glucose, which is poor medium in nutrients. Each of the strains showed distinct characteristics, such as yellow, white, brown, and pink colorations and rod and coccoid morphologies. With the use of a rich medium, such as LB (Luria-Bertani) $[1,20]$ or some other appropriate medium, we could have isolated more strains since the sediment is a very rich environment in microorganisms.

In addition to the bacterial community present in the samples, it should also be considered that the presence of fungi, possibly contributed to the reduction of the toxin, as any type of organic carbon. It has been demonstrated that fungi can even destroy cultures of cyanobacteria [12]. In addition organic matter may also have contributed greatly to reducing the concentration of toxin since it can provide carbon for the development of bacteria.
In this study the data of cyanobacteria biodegradation of the $\left[\mathrm{D}-\mathrm{Leu}^{-1}\right]$ microcystin-LR was performed in a laboratory experiment with the use of sediment from the estuary of Lagoa dos Patos - RS, Brazil. The fact that the occurrence of reduction in the concentration of [D-Leu ${ }^{1}$ ] microcystin-LR in the control group and that this reduction was stable from the third day on suggests that there is a potential for adsorption by the sediment. Some studies confirm that cyanobacteria toxins actually have their concentration reduced by the physical process of sediment adsorption [2,7,14,27,34]. In addition, the estuary receives a considerable amount of organic material from the Guaíba system, confirming earlier data that the presence of dissolved organic carbon and the abundance of microorganisms contribute to the rapid degradation of microcystis $[4,5]$.

The fact that the initial toxin concentration of approximately $5 \mu \mathrm{g} . \mathrm{mL}^{-1}$ dropped near zero from the sixth day is directly related to the set of microorganisms in the sediment, but there was an average decrease of $20 \%$ in the control and in the test. It is suggested that this $20 \%$ decrease, approximately, observed both in the control and the test samples over the course of three days, was due to the adsorption of [D-Leu ${ }^{1}$ microcystin-LR by the sediment particles.

The process of microcystin degradation is dependent on various factors, such as types of microorganisms present, dissolved concentration, water temperature, $\mathrm{pH}$ and availability of carbon [27,30]. A review of the organisms that carry out the biodegradation of microcystins has shown that several different strains of different extremities as to the physical and chemical characteristics are able to carry out the biodegradation of these toxins [18]. Additionally, these molecules are very stable in water; thus, conventional processes used in water treatment plants do not easily remove these toxins [16].

The concentration of toxin in the test group reached a measurement of zero after six days, indicating that the microbial community acted intensely on the toxin, completely removing it in a few days. The rate of exponential decay was measured as $0.8 \mu \mathrm{g} \cdot \mathrm{mL}^{-1}$.day ${ }^{-1}$, and the half-life was calculated to be 3.7 days. The half-lives calculated for microcystin-LR and microcystin-RR in other studies have varied from two to more than nine days [2]. Further, in experiments using sediments and lake water, it was shown that the rate of degradation for microcystins was higher in the sediment, indicating the importance of sediment in the process of the elimination of the toxin.

Studies have demonstrated that microorganisms capable of degrading hepatotoxins and anatoxin-a are found in different types of sediments from lakes where toxic cyanobacterial events both have and have not occurred [27]. Moreover, degradation occurs more rapidly with material collected during or after these events; in addition, aquatic bacteria with the capability of degrading different types of toxins have been isolated [17,21,33].

Among the seven isolated strains one of them was chosen to be tested as their capacity to biodegrade microcystins. The experiment was carried out and a population increase of this strain was verified during the experiment and the results were published [19]. 
Although the concentrations of toxins used in the studies are different, it was verified that the isolated bacteria had less biodegradation than with the use of the sediment. Possible explanations are related to the enzymatic mechanism of the isolated bacteria and its adaptation to using the toxin as a source of carbon. In addition, the sediment has a very large amount of bacteria that may be more able to degrade the toxin and also can exhibit cooperative behavior where one degrades one section and another degrades another part of the molecule. It is known that the toxic characteristic of the molecule is in the ADDA radical and that its cyclic structure is extremely stable and that even at high temperatures maintains its integrity [8]. However, the structure of the molecule can be altered by bacterial enzymes and in some cases after the attack of the bacterial enzymes there is the generation of sub-products [9] that could also be biodegraded by other bacteria present in the sediment.

Although in this comparative analysis the use of sediment for microcystin biodegradation has been more efficient, the biodegradation plays the main role in the degradation process and there are studies confirming the biodegradation of these toxins by bacteria in a period of 24 hours [10].

Thus, biodegradation seems to be an effective route for the elimination of microcystins in fresh water [2]. The role that the water column and sediment play in the degradation of microcystins in the aquatic environment has been studied previously [2,3,27], and it has been suggested that low levels of microcystins found in the environment are due to bacterial degradation [2].

Microcystins dissolved in the waters of reservoirs used as sources of drinking water and for fishing and recreation pose severe risks for both humans and animals. Thus, to reduce risks associated with microcystin contamination, it is need to further our understanding of the natural processes available for their degradation and elimination [2].

\section{Conclusion}

This study verified the sediment potential from Lagoa dos Patos-RS, (Brazil) to be used in technological applications for the biodegradation and/or bioremediation of toxins from cyanobacteria, especially microcystins. It was also confirmed the sediment's capacity for adsorption of [D-Leu $\left.{ }^{-1}\right]$ microcystin-LR and it was verified that it was responsible for the average of $20 \%$ of removal the total this toxin.

Thus the bacterial biodegradation process proved to be efficient and the use of sediment made possible a great concentration of microorganisms with capacity to act on the process of disruption of the toxin molecular structure, reducing its concentration. However, there are no studies that have been able to quantify and identify the total number of microorganisms present in the environment with capacity to contribute directly or indirectly to the biodegradation process of microcystins and that can be used in biotechnological applications.

\section{References}

[1] Bertani, G. 1951. Studies on lysogenesis. I. The mode of phage liberation by lysogenic Escherichia coli. J. Bacteriol. 62: 293-300.
[2] Chen, W., Song, L., Peng, L., Wan, N., Zhang, X., Gan, N. 2008. Reduction in microcystin concentration in large and shallow lakes: Water and sediment-interface contributions. Water Research, 42: 763-773.

[3] Chen, X., Yang, X., Yang, L., Xiao, B., Wu, X., Wang, J., Wan, H. 2010. An effective pathway for the removal of microcystin-LR via anoxic biodegradation in lake sediments. Water Research, 44: 1884-1892.

[4] Cousins, I. T., Bealing, D. J., James, H. A., Sutton, A. 1996. Biodegradation of microcystin-LR by indigenous mixed bacterial populations. Wat Res, 30: 481-485.

[5] Gomes, A. M. A.; Oliveira, A. C. P.; Azevedo, S. M. F. de O. 2009 Efeito de diferentes concentrações de carbono orgânico dissolvido e bactérias na degradação de microcistinas (cianotoxina). Oecol. Bras. 13: 402-412.

[6] Grosse, Y., Baan, R., Straif, K., Secretan, B. Ghissassi, F. E., Cogliano, V. 2006. Carcinogenicity of nitrate, nitrite, and cyanobacterial peptide toxins. Lancet oncol. 7: 628-629.

[7] Grützmacher, G.; Wessel, G.; Klitzke, S. and Chorus, I. 2010. Microcystin elimination during sediment Contact. Environment Science Technology. 44, 657-662.

[8] Harada, K-I, Tsuji, K; Watanabe, M.F. Stability of microcystins from cyanobacteria - III. Effect of $\mathrm{pH}$ and temperature. Phycologia 1996; 35(6): 83-8.

[9] Harada, K- I; Imanishi, S; Kato, H; Mizuno, M; Ito, E.; Tsuji, K. 2004. Isolation of Adda from microcystin-LR by microbial degradation. Toxicon, 107-109.

[10] Imanishi, S.; Kato, H.; Mizuno, M.; Tsuji, K. and Harada, K.-I. 2005. Bacterial Degradation of Microcystins and Nodularin. Chem. Res. Toxicol. 591-598.

[11] Holst, T.; Jorgensen, N. O. G.; Jorgensen, C. and Johansen, A. 2003. Degradation of microcystin in sediments at oxic and anoxic denitrifying conditions. Water Research 37, 4748-4760.

[12] Jia, Y.; Han, G.; Wang, C.; Guo, P., Jiang, W.; Li, X.; Tian, X. 2010. The efficacy and mechanisms of fungal suppression of freshwater harmful algal bloom species. Journal of Hazardous 774.

[13] Krishnamurthy, T., Szafraniec, L., Hunt, D.F., Shabanowitz, J., Yates, J.R., Hauer, C.R., Carmichael, W.W., Skulberg, O., Codd, G.A. Missier, S., 1989. Structural characterization of toxic cyclic peptides from blue-greeen by tandem mass spectrometry. Proc. Natl. Acad. Sci. USA 86, 770-774.

[14] Lahti, K.; Kilponen, J.; Kivimaki, A. L. Erkomaa, K. Sivonen, k. 1996. Removal of cyanobacteria and their hepatotoxins from raw water in soil and sediment columns. In: Kivimaki, A. L. Suokko, T (Eds), artificial recharge of groundwater. NHP/Report $n^{\circ} 38$, Helsinki, pp 187-195.

[15] Lawton, L. A.; Edwards, C.; Codd, G. 1994. Extraction and Highperformance liquid chromatographic method for the determination of microcystin in raw and treated waters. Analyst, 119: 1525-1530.

[16] Lawton, L. A. \& Roberstson, P. K. J. 1999. Physico-chemical treatment methods for the removal of microcystins (cyanobacterial hepatotoxins) from potable waters. Chem Soc Rev, 28: 217-224.

[17] Lemes, G. A. F., Kersanach, R., Pinto, L. S., Dellagostin, A. O., Yunes, J. S., Matthiensen, A. 2008. Biodegradation of microcystins by aquatic Burkholderia sp. from a South Brazilian coastal lagoon. Ecotox Environ Safe, 69: 358-365.

[18] Lemes, G. A. F. \& Yunes, J. S. 2014. Microcystins Biodegradation - A Review. LAP Lampert Academic Publishing Germany.

[19] Lemes, G. A. F., Kist. L. W., Bogo, M. R. and Yunes, J. S. 2015. Biodegradation of [D-Leu $]^{1}$ microcystin-LR by bacterium isolated from sediment of Patos Lagoon estuary, Brazil. Journal of Venomous Animal and Toxins including Tropical Diseases, 21:4.

[20] Luria, S. E. and J. W. Burrous. 1957. Hybridization between Escherichia coli and Shigella. J. Bacteriol. 74: 461-476.

[21] Maruyama, T., Park, H. D., Ozawa, K., Tanaka, Y., Sumino, T., Hamana, K., Hiraishi, A., Kato, K. 2006. Sphingosinicella microcystinivorans gen. nov., sp. Nov., a microcystin-degrading bacterium. Int J Syst Evolut microbiol, 56: 85-89.

[22] Matthiensen, A.; Yunes, J. S. \& Codd, G. A. 1999. Ocorrência, distribuição e toxicidade de cianobactérias no estuário da Lagoa dos Patos, RS. Revista Brasileira de Biologia. 59(3): 361-376.

[23] Matthiensen, A. 2000. Environmental and laboratory studies on the properties and fate of microcystins from the cyanobacterium Microcystis. Phd thesis, University of Dundee, Dundee, Scotland, UK. 307p. 
[24] Matthiensen, A., Beatie, K. A., Yunes, J. S., Kaya, K., Codd, G. A. 2000a. [D-Leu ${ }^{1}$ ] Microcystin-LR, from the cyanobacterium Microcystis RST 9501 and from a Microcystis bloom in the Patos Lagoon estuary, Brazil. Phytochemistry, 55: 383-387.

[25] Morsen, A. \& Rehm, H. J. 1987. Degradation of phenol by a mixed culture of Pseudomonas putida and Crytococcus elinonii adsorbed on activated carbon. Applied Microbial Biotecnology. 26: 283-288.

[26] Nealson, K. H. 1997. Sediment bacteria: Who's there, What are they doing and what's new? Annu. Rev. Earth Planet. Sci. 25: 403434.

[27] Rapala, J.; Lahti, K.; Sivonen, K.; Niemelä, S. I. 1994 Biodegradability and adsorption on lake sediments of cyanobacterial hepatotoxins and anatoxin-a. Lett Appl Microbiol, 19:423-428.

[28] Revathy, T.; Jayasri, M. A. and Suthindhiran, K. 2015. Biodegradation of PAHs by Burkholderia sp. VITRSB1 Isolated from Marine Sediments. Scientifica.2015: 867586.

[29] Rippka, R.; Deruelles, J.; Waterbury, J. B.; Herdman, M.; Stanier, R. Y.1979. Generic Assignments, Strain Histories, and properties of pure cultures of cyanobacteria. Journal General microbiology, 111: $1-61$.

[30] Roberston, P. K. J.; Lawton, L. A.; Cornish, B. J. P. A. 1999. The involvement of phycocyanin pigment in the photodecomposition of the cyanobacterial toxin, microcystin-LR. Journal of Porphyrins and Phthalocyamines, 3: 544-551.

[31] Santos, I. R.; Baisch, P.; Lima, G.; Mirlean, N.; Griep, G.; SilvaFilho, E. V. 2004. Análise estatística multivariada de parâmetros geoquímicos em sedimentos da laguna dos Patos. Geochim. Brasil, 1: $38-45$.
[32] Santos, P. R. N. de M. dos; kolm, H. E.; Sautter K. D. 2008 Bactérias em sedimentos da região entre-marés da baía de Guaratuba, Paraná, Brasil. Braz. J. Aquat. Sci Technol. 1:9-17.

[33] Takenaka, S. and Watanabe, M. F. 1997. Microcystin-LR degradation by Pseudomonas aeruginosa alkaline protease. Chemosphere, 34: 749-757.

[34] Tsuji, K. Masui, H. Uemura, H. mori, Y., Harada, K.-I. 2001. Analysis of microcystins in sediments using MMPB method. Toxicon, 39:687-692.

[35] Wiegand, C.; Pflugmacher, S. 2005. Ecotoxicological effects of selected cyanobacterial secondary metabolites a short review. Toxicology and Applied Pharmacology, 203: 201-218.

[36] Windom, H.; Niencheski, F. 2003. Biogeochemical process in a freshwater-seawater mixing zone in permeable sediments along the coast of Southern Brazil. Marine Chesmistry, 83:121-130.

[37] Yunes, J. S.; Niencheski, L. F. H.; Salomón, P. S.; Marcelo, P.; Beattie, K. A.; Ragget, S. L. \& Codd G. A. 1994. Development and toxicity of cyanobacteria in the Patos Lagoon estuary, Southern Brazil. IOC Workshop Report, 101. annex III, COI/UNESCO Publ.: 14-19.

[38] Yunes, J.S.; Salomón, P.S.; Matthiensen, A.; Beattie, K. A.; Raggett, S. L.; Codd, G. A. 1996. Toxic blooms of cyanobacteria in Patos Lagoon Estuary, southern Brazil. Journal of Aquatic Ecosystem Health, 5: 223-229.

[39] Yunes, J. S.; Niencheski, L. F. H.; Salomón, P. S.; Marcelo, P.; Beattie, K. A.; Ragget, S. L. \& Codd G. A. 1998. Effect of nutrient balance and physical factors on blooms of toxic cyanobacteria in the Patos Lagoon, southern Brazil. Verh. Internat. Verein. Limnol. 26, 1796-1800.

[40] Yunes, J. S. 2009. Florações de Microcystis na Lagoa dos Patos e o seu estuário. 20 anos de estudos. Oecol. Bras. 13(2): 313-318. 